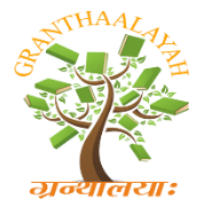

\author{
INTERNATIONAL JOURNAL OF RESEARCH - \\ GRANTHAALAYAH \\ A knowledge Repository
}

Social

\title{
LEGAL DIMENSION OF CHILD MARRIAGES IN TURKEY: COMPARED WITH THE EASTERN EUROPE AND MIDDLE EAST COUNTRIES
}

\author{
Oğuz Polat ${ }^{1}$, Zeynep Reva ${ }^{2}$ \\ ${ }^{1}$ Prof. Dr. Acıbadem Mehmet Ali Aydınlar University, Faculty of Medicine, Department of \\ Forensic Medicine. İstanbul, Turkey \\ ${ }^{2}$ Attorney-at-Law, LL.M., Ph.D. Candidate. Istanbul Medeniyet University, Medical Law \\ Department Doctorate Program. İstanbul
}

\begin{abstract}
Child marriage is defined as a marriage before the age of 18. In many countries, a significant number of girls still marry before the age of 18. The country governments and international communities are increasingly aware of the negative impacts of child marriages, but the actions to end the practice is still limited.

Child marriage threatens particularly girls' lives and health, and it limits their future prospects. Early marriages are not considered as a "problem" by the majority of the society where as it is a phenomenon that has been existing for long years in our country. It is observed that one of the most important sources of legitimacy of marriage is public accord and these marriages are realized mostly in the framework of this accord. Patriarchal and traditional social structure have unfortunately normalized and legitimized early marriages.

It is necessary to hold meetings to create and develop awareness for implementation of Turkish Civil Code, Turkish Penal Code and Law on Protection of Minors. It will be therefore possible to ensure that children, families and people understand what kind of problems and penal responsibilities that early marriage of children constitutes

Child marriage is a problem that prevents the exercise of human rights, undermines the status of women and deprive child from their main rights including especially the education. Their marriages are a field that must be struggled with in Turkey targeting social gender equality.
\end{abstract}

Keywords: Child Marriage; Early Marriage; Child Brides.

Cite This Article: Oğuz Polat, and Zeynep Reva. (2019). "LEGAL DIMENSION OF CHILD MARRIAGES IN TURKEY: COMPARED WITH THE EASTERN EUROPE AND MIDDLE EAST COUNTRIES." International Journal of Research - Granthaalayah, 7(4), 338-354. https://doi.org/10.29121/granthaalayah.v7.i4.2019.916. 


\section{Introduction}

Child marriage is marriage of the persons under 18 years of age, and it is a fundamental violation of human rights.

Child marriage is a fundamental violation of human rights. Child marriage also affects boys, but to a lesser degree than girls (1). Many factors interact to place a girl at risk of marriage, including poverty, the perception that marriage will provide 'protection', family honour, social norms, customary or religious laws that condone the practice, an inadequate legislative framework and the state of a country's civil registration system. Child marriage often compromises a girl's development by resulting in early pregnancy and social isolation, interrupting her schooling, limiting her opportunities for career and vocational advancement and placing her at increased risk of domestic violence. (1)

Child marriage is fuelled by gender inequality, poverty, traditions, and insecurity. But drivers will vary from one community to the next and the practice may look different across regions and countries, even within the same country. (2)

Child brides are neither physically nor emotionally ready to become wives and mothers. They face more risks of experiencing dangerous complications in pregnancy and childbirth, contracting HIV/AIDS and suffering domestic violence. With little access to education and economic opportunities, they and their families are more likely to live in poverty. (2)

When children marry, their education suffers; many girls must drop out of school once they marry $(3,4)$. In addition, early marriages commonly result in early childbirth, which can have serious effects on both mothers and babies $(5,6)$. Both infant mortality and maternal mortality are significantly higher for very young mothers $(4,7)$. Worldwide, mothers aged 15 to 19 are twice as likely to die in childbirth as women giving birth in their 20s, and girls under age 15 are five times more likely to die in childbirth. (8)

There are a great number of causes of child marriages in our country where types of forced marriage like Taygeldi marriage, marriage with brother-in-law (Levirant), marriage with sister-inlaw (Sorarat), blood money marriage, marriage against bridewealth, berder (berdel) marriage, abduction, co-wife marriage, marriage for revenge. It is possible to define these causes as lack of education, custom and tribe factor, misinterpretation of religious knowledges, domestic violence, economic reasons and exposure to abuse and rape.

Turkey has one of the highest rates of child marriage in Europe with an estimated $15 \%$ of the girls getting married before the age of 18. This statistical data does not include unofficial religious marriages, therefore the rate is higher.

\section{Methodology}

This conceptual paper is based on a systematic review and analysis of research and data from the literature, and the statistics of Turkish Statistical Institute, Ministry of Justice, UNICEF and World Bank. The method of this study is literature ve statistics screening method. The literature review 
was carried out in "Acibadem Mehmet Ali Aydınlar University Database", "Ulakbim Turkish Academic Network and Information Center", "Google Scholar". The research was made between November 2018 and January 2019 and 4 keywords were used: "child marriage", "early marriage", "child bride", and "forced marriage".

\section{Results}

\subsection{Definition and Terminology}

Regarding the definition article of "child" of the Convention on the Rights of the Child dated 1989, the act of marriage under the age of 18 may be named as "child marriage", "early marriage" "child brides" or "child mothers". It is not preferred to use "child brides" as terminology, since these two words are actually words that express two beautiful concepts. However, when they are used together, they express a terrible action. Therefore, it is preferred to use the term "child marriage" and/or "early marriage" instead of "child brides".

\subsection{Child Marriages in Turkey}

\subsubsection{In General}

Turkish Civil Code (9) Article 124 pointed out 17 as age limit for capacity of marriage and allows marriage of minors who are 17 years old with the consent of their family. Even minors being 16 years old can marry through a court verdict in case of presence of special and enforcing circumstance.

The Civil Code article 124 specified 17 as age limit for capacity of marriage and allows marriage of minors who are 17 years old with the consent of their family. Even minors being 16 years old can marry through a court verdict in case of presence of special and enforcing circumstance.

There is practice that has been traditionalized for years in Turkey. Especially in east and south east, girls are caused to marry with children when they come to 12-13 years old. These marriages are not performed with wedding ceremonies and civil marriage; they are performed with imam marriage. Early marriage of girls means that they are imprisoned at home in minor age while they have to go to school and that they are obliged literally to play house endlessly. Girls who get married in childhood years with the coercion and pressure of their family and society get under the charge of motherhood without enjoying their childhood and they are much damaged psychologically in particular. These children who give birth before growing to full biological maturity grow while raising their babies. But these babies pay for it when they grow as their mothers are uneducated, inexperienced and immature. In other words, the trauma that is suffered is not limited with the child; it passes to their babies and survives from generation to generation.

Early marriages is not considered as a "problem" by the majority of the society where as it is a phenomenon that has been existing for long years in our country. It is observed that one of the most important sources of legitimacy of marriage is public accord and these marriages are realized mostly in the framework of this accord. Patriarchal and traditional social structure have unfortunately normalized and legitimized early marriages. (10) 


\subsubsection{Reasons of Child Marriage}

The main reasons underlying the early marriage of girls in childhood years can be listed as follows. (11)

Table 1: The Main Reasons Underlying the Early Marriage of Girls in Childhood Years

\begin{tabular}{|l|l|}
\hline a) & Lack of Education \\
\hline b) & Custom and Tribe Factor \\
\hline c) & Misinterpretation of Religious Knowledge \\
\hline d) & Domestic Violence \\
\hline e) & Economic Reasons \\
\hline f) & Exposure to Abuse and Rape \\
\hline
\end{tabular}

a) Lack of Education: It is observed that the rate of girls married in childhood age is encountered more frequently in regions where the rate of being educated is low revealing that lack of education is a very fundamental cause.

Lack of education is either cause or result of early marriages. The best way to increase the age of marriage is to allow children to get educated. The fact that $20 \%$ of women in Turkey are still illiterate demonstrates that the rights that were granted to women in the foundation of Republic have never been implemented completely by the State. It is required to ensure the implementation of current laws including especially the right of education (12). With reference to a study (11) performed in 2009, 693 students who were absent from school because of early marriage and engagement consisted of 675 girls and 18 boys. As it is seen, there is a significant difference against girls.

b) Custom and Tribe Factor: The most common of reasons underlying the early marriage of girls in childhood years is "customs". Despite the changing socio-cultural structures especially in eastern and south eastern regions; customs and tribal traditions preserve their significance in some regions where traditional and cultural effects, habits and pattern judgments dominate. Customs that we can define as unwritten social rules is a concept that allows early marriages. Existence of a great number of proverb justifying marriage in childhood age in Turkish reveals the effect of the factor of custom: "girl is in cradle and dowry is in coffer", "Girl in fifteen is either with husband or on ground", "Iron in temper, belle in age", "Whoever get married early takes child, whoever get up early makes way" "Whoever got married early has not been mistaken" and so on. $(11,13)$

c) Misinterpretation of Religious Knowledges: Religion widely affects the social, psychological and cultural lives of individuals and the injured parties in these lives are generally women. One of the most dangerous mistakes that are made is to misinterpret the religious knowledge and to demonstrate that marriage of individuals in childhood is normal by referring to religious sources.

d) Domestic Violence Girls exposed to violence and coercion in their family confirms the marriage by considering the marriage as a salvation but they may generally be exposed to violence similarly after marriage.

e) Economic Reasons: Another of significant reasons of forced early marriages is the economic factors. The material condition so called "bridewealth" is imposed for the performance of marriage in some regions of our country. Some families have their children marry with wealthy individuals by pressure. An important decision like marriage that will affect directly their lives gains economic dimensions and is considered a solution to poverty. 
f) Exposure to Abuse or Rape The solution offered to the abused and raped girl is unfortunately her marriage with the culpable of this crime. Because, then the tarnished reputation of the family will be cleaned and the event will be closed. However, getting married with the assaulter will cause permanent psychological damages for that girl.

\subsubsection{Types}

Enforced marriages in our country can be classified as follows:

Table 2: Types of Enforced Marriage (14)

\begin{tabular}{|l|l|}
\hline a) & Taygeldi marriage \\
\hline b) & Marriage with brother-in-law (Levirant) \\
\hline c) & Marriage with sister-in-law (Sorarat) \\
\hline d) & Marriage against Blood Money \\
\hline e) & Marriage with Bridewealth \\
\hline f) & Berder (berdel) marriage \\
\hline g) & Abduction \\
\hline h) & Marriage with co-wife \\
\hline i) & Marriage for revenge \\
\hline j) & Betrothed in the cradle \\
\hline
\end{tabular}

a) Taygeldi marriage: It is known also as "with mother and daughter" or "with inside and outside" Marriage of two widows having children from different genders in company with the marriage of children of them $(14,15)$. It is not observed in west. It is specific to Islamic countries. In the event that both widows have children in marriage age or in early age from different genders and in equal number, then the real or symbolic marriage of widows and children is called as taygeldi marriage.

b) Marriage with brother-in-law (Levirant): It refers the marriage of brother of a deceased elder brother with the wife of his elder brother. It is frequently seen in Eastern and Southeastern Anatolia. The customary power that is compulsory to comply in Eastern Anatolia and Southeastern Anatolia makes pressure in direction to get married with the younger brother but absolutely not the elder brother of the deceased person. The elder brother is deemed as the elder brother of the bride so it is deemed that they are not eligible to get married with each other. This kind of marriage is not much encountered in our western regions.

The law referred it as "Atypical form of marriage"; if the brother is married, it is colloquially referred as "co-wife" or "with inside and outside with partner". Only religious marriage is solemnized and the born child is registered in the civil registry of the 1 st wife. $(15,16)$

This marriage is realized with the choice of the family not the choice of the individuals to get married with. The purpose is to preserve the integrity of the family and to prevent the children to be abandoned and suppressed. The married woman has joined to that family and must not leave it anymore. 
c) Marriage with sister-in-law (Sorarat): It is a special cultural tradition. The marriage of widow man with the sister of the sister of his ex-wife. It is tried to be rationalized with the consideration that the aunt selected as stepmother will be more tolerant to the orphaned children. (14)

d) Blood Money: It is a kind of marriage where daughters are granted in company with materials assets against blood money to the families that have blood feud between them. It is formed by the custom as it is the case in levirant. It is encountered more frequently in regions of Eastern and Southeastern Anatolia like other enforced marriages. (14)

There is not there any consent of the marrying individuals. Marrying against blood money is a primitive form of marriage based on lack of education. The only positive aspect of such marriages is the fact that they terminate blood feuds. (17)

e) Marriage with Bridewealth: Bride wealth refers to the money paid by the young man to get married to the family of the girl. It can be granted in gold, house, garden, field and animal as well as it can be paid in cash money. It is commonly performed in rural parts of the Regions of Eastern and Southeastern Anatolia. (14)

f) Berder (berdel) Marriage: It is known as "Kepir" in Hakkari, "Performing Exchange" in Denizli-Aydın and "Berdel" in Eastern and Southeastern Anatolia. The exchange of sisters by two men in marriage age from one to the other. Generally, it is performed because of being able to pay bridewealth (for poor families) or in order to further reinforce the relations like sheikhdom and landlord status for ones who are from higher socioeconomic level. It is done with the purpose to ensure the efficiency in family and the control over children. (14)

g) Abduction: Abduction is committed in events that families object a marriage. Claiming bridewelth is also a factor in this. (14)

h) Marriage with co-wife: The man whose wife is infertile or cannot deliver a son is made to marry again and then the man lives with multiple women usually in same home. It is commonly performed in the Regions of Eastern and Southeastern Anatolia. (14)

i) Marriage for Revenge: Some families having blood feud between them use this means in order to tarnish the opposite family's honor and to damage their reputation. (14)

j) Betrothed in the cradle: Friends, fellows, neighbors or relatives who love each other very much perform engagement of their children when they are in cradle by tying notching (mark, cloth) to cradle and thus promise that their babies will marry each other (14)

\subsubsection{Statistics on Child Marriage in Turkey}

Turkey has one of the highest rates of child marriage in Europe with an estimated $15 \%$ of the girls getting married before the age of 18 . However, statistical data available may not be representative of the scale of the issue since some of the child marriages are unregistered and take place as unofficial religious marriages. (18) 
Turkey, minimum legal age of marriage was raised to 17 in 2002 (under Article 124 of the Turkish Civil Code). The exceptions allow marriages under 17 years old with parental consent and at 16 years old with court authorization.

Mean age at first marriage was 27.7 for males and 24.6 for females in 2017. (19)

According to the marriage statistics of TURKSTAT, while the proportion of legal child marriages for girls aged between 16 and 17 within the total legal marriages were $6.2 \%$ in 2013, it declined to $4.2 \%$ in 2017. In province-based analyzes in 2017, the province with the highest proportion of child marriages for girls was Ağrı with the proportion of $16.6 \%$. This province was followed by Muş with $16.1 \%$ and Bitlis with $12.3 \%$. The three provinces with the lowest proportion of child marriages for girls within total marriages were Tunceli with $0.4 \%$, Rize with $1.1 \%$ and Trabzon with $1.4 \%$ respectively $(19,20)$. The provinces with the highest rates are located in East and Southeast Anatolia in Turkey.

In 2017; the total number of all marriages is 569.459, and 23.906 of it is girl child marriage. (19)

Child marriage statistics are officially published for children 16-17, but data on child marriage before the age of 16 is not available.

According to the data of Ministry of Family and Social Policies, the number of girls married in minor age was declared as 45,738 in 2010, 42,700 in 2011, 40,428 in 2012, 37,481 in 2013, 34,629 in $2014,31,337$ in 2015. (21) (Figure 1)

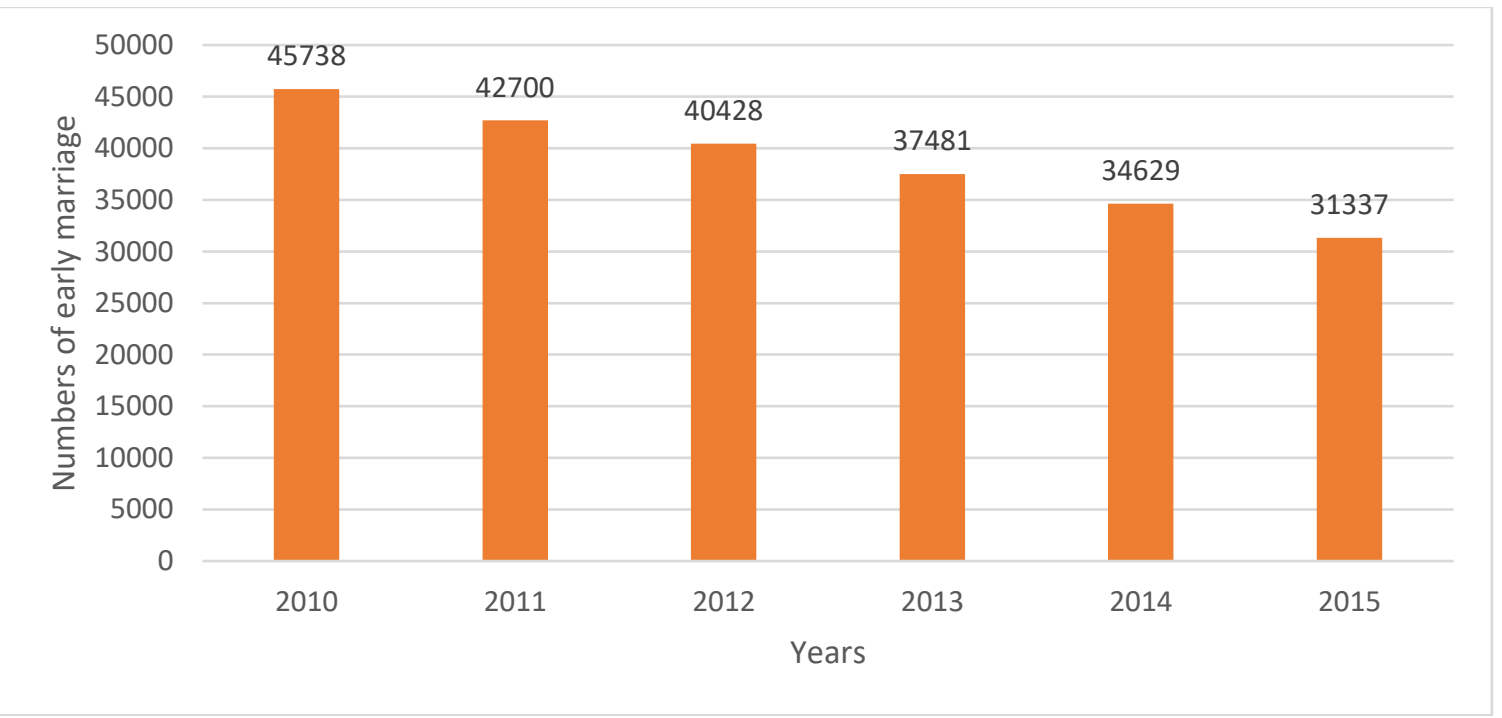

Figure 1: The number of girls married in minor age

According to the data of 2017 of the Ministry of Justice (22); the number of lawsuits in subject of permission for marriage filed in Family Courts is 8,581, and of the cases, 7384 were fully or partially accepted; and The province with the highest rate of these lawsuits is located in Southeast Anatolia in Turkey. This data reveals only that the number of girls married officially in minor age is high. 
The Human Rights Commission of National Assembly that went to examine the event of sexual abuse performed to children by many people in Siirt located in the southeastern region of Turkey detected in its investigation that there were many girls who had become mother in minor age. This is an existing but not expressed subject. Girls attend only the compulsory primary school and it is observed that many families do not allow their daughters to attend it. Then they are made to get married while they are still children when they come to 12-13 years with the consideration that her age came so that she must be made to marry before she is abducted, or she finds somebody. There it is convenient to note that "bridewealth" is received and so that this event turn to the sale of girls.

It was pointed out in the report released by the Commission of Human Rights in light of information taken from the authorities of Police Department of Siirt that 31 girls under 18 years gave birth in Siirt during 2008. 5 of them were between 12 and 15 years. This number was 28 in 2009, the 6 of which was in range of 10-15 age including 1 in 10 years old. 17 girls under 18 years including 4 between 12 and 15 years gave birth in the 4-month period of 2010. (23) (Figure 2)
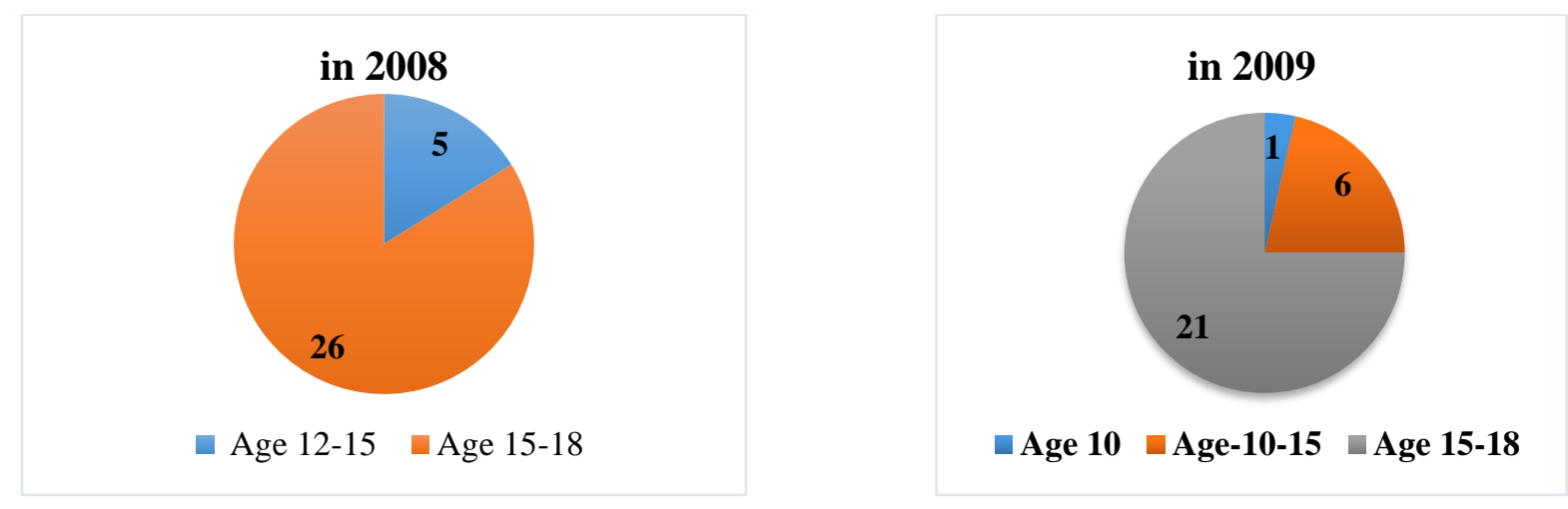

\section{in the first four months of $\mathbf{2 0 1 0}$}

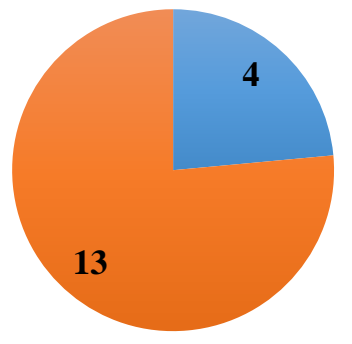

- Age 12-15 age 15-18

Figure 2: Number of girls under 18 years gave birth in Siirt

\subsection{Child Marriage in the World}

Child marriages can be faced in every region all over the world, from the Sub-Saharan to Latin America, Middle East to Europe. 
Research conducted by the World Bank and United Nations organisations point out that there is a correlation between child marriages, in particular among girls, and the level of development of the country and the poverty of the family. In countries around the world, girls and boys from lowincome families are more likely to be married as children than those from richer families. $(5,24)$

Across the globe, levels of child marriage are highest in sub-Saharan Africa, where around 4 in 10 young women were married before age 18, followed by South Asia, where 3 in 10 were married before age 18. Lower levels of child marriage are found in Latin America and Caribbean (25\%), the Middle East and North Africa (17 per cent), and Eastern Europe and Central Asia (11\%). (18) (Figure 3)

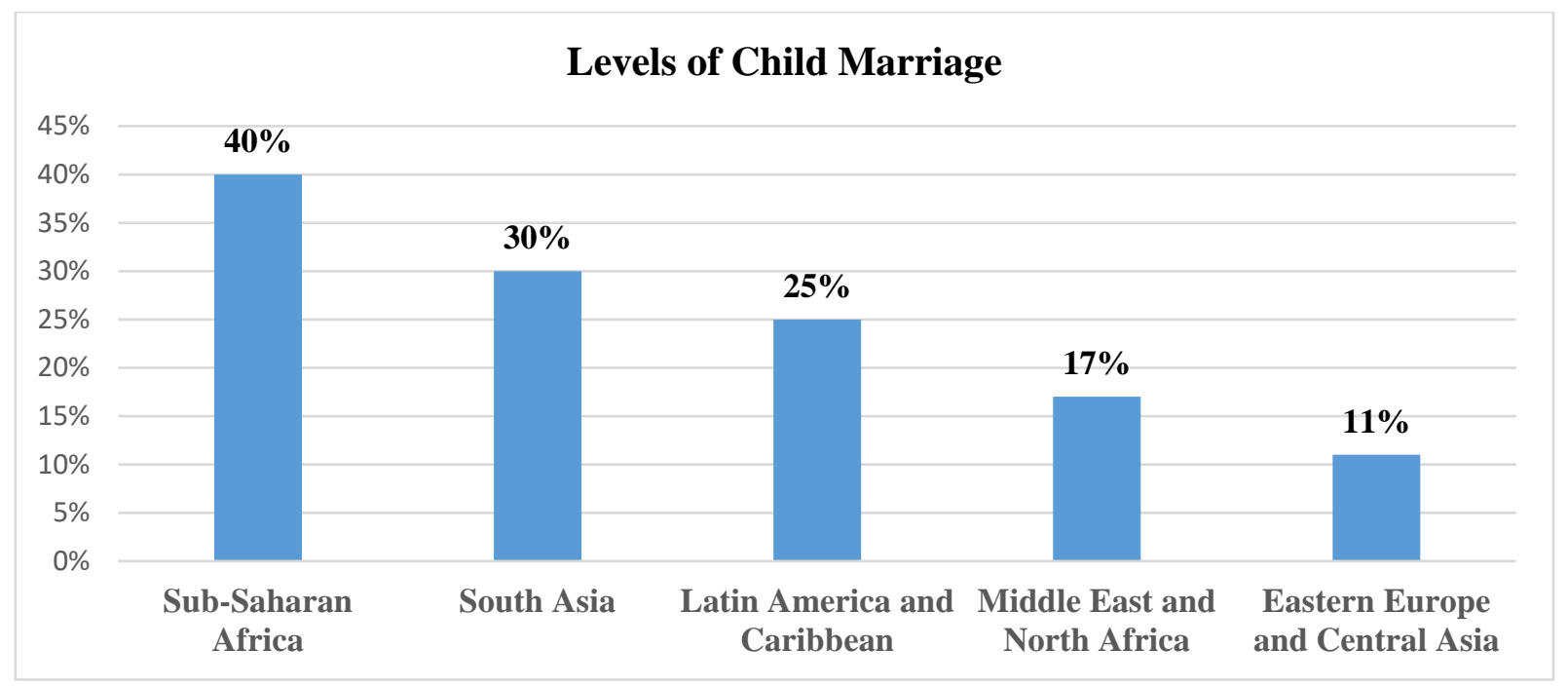

Figure 3: Levels of Child Marriages

The total number of girls married in childhood is estimated at 12 million a year. The new figures point to an accumulated global reduction of 25 million fewer marriages than would have been anticipated under global levels 10 years ago. However, to end the practice by 2030 - the target set out in the Sustainable Development Goals - progress must be significantly accelerated. Without further acceleration, more than 150 million additional girls will marry before their 18th birthday by 2030 . Worldwide, an estimated 650 million women alive today were married as children. While South Asia has led the way on reducing child marriage over the last decade, the global burden of child marriage is shifting to sub-Saharan Africa, where rates of progress need to be scaled up dramatically to offset population growth. Of the most recently married child brides, close to 1 in 3 are now in sub-Saharan Africa, compared to 1 in 5 a decade ago. (25)

Girls married in minor age suffer much more health problems during pregnancy and in delivery with respect to women who are married in twenty somethings. Deaths related to conceive or deliver baby occur very frequently among girls in age group 15-19 and about 70,000 girls die as a result of conceiving or delivery. Furthermore, the babies they deliver die either miscarriage or in the following 1 month. (26)

According to the publication of WHO (World Health Organization); a number of girls exceeding 140 million will get married between 2011-2020 and 50 million of them will be under 15. (27) 
According to UNICEF data updated in 2018 March (28), the highest rate of child marriage is in Niger by $76 \%$ where the rate of child marriages in and under age 15 is $28 \%$. Niger taking the first place in child marriage is followed consecutively by Central African Republic, Chad (has the highest rate of the marriages under age 15 by 30\%), Bangladesh, Burkina Faso, Mali, Southern Sudan and Guinea. In each of the countries taking the 8 first ranks of this list comprising 197 countries, the rate of people who get married in minor age is above $50 \%$. Turkey occupies $86^{\text {th }}$ place of this list by the rate of $15 \%$ and the rate of chldren who get married in and under 15 is $1 \%$ for our country. As the statistics here include solely the civil marriages but exclude religious marriages, it is considered that this rate is higher.

Table 3: Child Marriage Ranking

\begin{tabular}{|l|l|l|l|}
\hline Rank & Country & Married by 15 \% & Married by 18 \% \\
\hline 1 & Niger & 28 & 76 \\
\hline 2 & Central African Republic & 29 & 68 \\
\hline 3 & Chad & 30 & 67 \\
\hline 4 & Bangladesh & 22 & 59 \\
\hline 5 & Burkina Faso & 10 & 52 \\
\hline 6 & Mali & 17 & 52 \\
\hline 7 & South Sudan & 9 & 52 \\
\hline 8 & Guinea & 19 & 51 \\
\hline 86 & Turkey & 1 & 15 \\
\hline
\end{tabular}

World leaders made the commitment to extinguish child marriage as of 2030 in the scope of Sustainable Development Targets (L) of United Nations. Despite the rate of child marriages have decreased by one fifty with respect to ten years ago, there is a long way to take to eliminate child marriages until 2030. Therefore, the progress must be further accelerated to put an end to child marriage until 2030. Otherwise, more than 150 million girls will get married under 18 until 2030. (25)

\subsection{Legal Dimension of Child Marriages}

\subsubsection{In Turkey}

The article 10 of the constitution prohibits "discrimination between genders". The Turkish Civil Code includes a legal provision in accordance with it, and the Code, sets forth a common age without discrimination between women and men unlike the previous code in which there was a different age for men. According to the article 124 of Turkish Civil Code; neither man nor woman cannot get married unless they turn their 17 years. As the age of puberty (majority) is 18 principally according to Turkish law, individuals who have turned 17 years can get married only with the consent of their parents. In extraordinary situations, the marriage of man or woman who has turned 16 years can be possible through a judicial decision. Consent of parents is not requisite in marriage performed through judicial decision, only their opinions are taken if possible. "Extraordinary Situation" is considered generally as circumstances where the woman is pregnant or has child. 
The matter of increasing the ages that had not been accepted in previous law drafts was adopted by the law dated 2001 with the reason that the permission to marriage of people in minor age especially girls was causing negative impacts in pscychologic and biologic term. (29)

According to the article 103/1 titled "Sexual Abuse of Minors" of Turkish Penal Code (30), it is possible to sentence culpables of the crime of sexual abuse realized against minors under 15 either with the consent of the minor or based on violence, threat, cheat or other cause influencing the will to imprisonment from five to eight years, and it is possible to condemn such culpables of such crimes from eight to fifteen years if the abuse is realized by inserting organ or other object to body according to the second paragraph. In other words, even if a child under 15 years get married with her own consent (this marriage is unofficial marriage), the man will be possibly sentenced to imprisonment in the event of occurrence of sexual relation.

According to the Article 104 titled "Sexual Relation with Minor" of Turkish Penal Code; the person who had sexual relation with a minor who has turned 15 years without violence, threat and cheat can be sentenced to imprisonment from six months to two years upon complaint. In other words, when a minor above 15 is made to be married unofficially; the spouse who gets in sexual relation with the minor is not penalized so long as this act is not complained. The right of complaint is granted exclusively to the victim so that the related person will not be penalized if there is not any complaint of the victim. (31)

The most important matter here is prevention of marriages against legal legislation through religious marriage. The article 230 of Turkish Penal Code for this purpose stipulated imprisonment to the person who performed religious ceremony so called colloquially as religious solemnization or imam solemnization without seeing the certificate of civil marriage. But this article was abated by the verdict of Constitutional Court dated 27/5/2015 (32). That is to say than in the event of realization religious solemnization for a child under 15 , the person who performs the solemnization will not be penalized under the Article 230/6 of Turkish Penal Code.

The matter of early marriage of minors is subject to different regulations and different age limitations in different codes. While there is the age restriction is 17 for marriage in Turkish Civil Code, the age limit for execution of penalty is 15 according to the Turkish Penal Code. On the other hand, every individual under 18 years old is subject to special protection according to Child Protection Code. Hence, the article 1 of the Convention on Rights of the Child of United Nations of which Turkey is also signatory state defines every human being below the age of eighteen years as child. As it is seen, the matter of age is not uniform in consideration of national legal regulations and international texts.

\subsubsection{Globally}

Most countries around the world have laws that set a minimum age of marriage, usually at age 18 . However, many countries provide exceptions to the minimum age of marriage, upon parental consent or authorisation of the court. 
According to a 2013 mapping of minimum age of marriage laws by the World Policy Analysis Center, 93 countries legally allow girls to marry before the age of 18 with parental consent. Legal frameworks can reinforce, rather than challenge, gender inequalities. (33)

In 7 countries, there is no nationally set minimum legal age of marriage, including the United States, where in some states there is no minimum age below which marriage cannot occur, provided that parental consent is given (33). In a total of 54 countries, girls are legally permitted to marry between 1 and 3 years younger than boys. In no country can boys be married at a younger age than girls. (34)

There are no cases where the minimum age for boys to be married is younger than the minimum age for girls. The minimum age of marriage is the youngest age at which a girl or boy is allowed to marry with no restrictions, only with parental consent, or under customary or religious law. Since the majority of child marriages occur with parental permission and involvement, we do not consider that this requirement alone is enough to protect at-risk children. In many countries civil law exists alongside parallel customary and religious legal systems. These parallel laws often do not preclude early marriage, weakening civil law prohibitions and exposing, girls in particular, religious and ethnic communities to early marriage.

Compared Turkey with the Eastern Europe Countries, the minimum age of marriage with parental consent is 17 in Turkey, whereas it is 18 in the Eastern Europe Countries. Besides that the characteristic is very similar to eacho ther. If it is permitted with court approval, 15-year-old girls can get married in Albania and Slovenia, whereas in the other Eastern Europe countries and Turkey it is prohibited. The following table points out comparison between Turkey and Eastern Europe Countries on the basic legal situations on child marriage. (34) (Table 4)

Table 4: Comparison Between Turkey and Eastern Europe

\begin{tabular}{|c|c|c|c|c|c|}
\hline Country & $\begin{array}{c}\text { What is the } \\
\text { minimum } \\
\text { age of } \\
\text { marriage } \\
\text { for girls? }\end{array}$ & $\begin{array}{c}\text { What is the } \\
\text { minimum } \\
\text { age of } \\
\text { marriage for } \\
\text { girls with } \\
\text { parental } \\
\text { consent? }\end{array}$ & $\begin{array}{c}\text { Is there a } \\
\text { gender } \\
\text { disparity in } \\
\text { the minimum } \\
\text { legal age of } \\
\text { marriage? }\end{array}$ & $\begin{array}{c}\text { When all } \\
\text { exceptions are } \\
\text { taken into } \\
\text { account, what is } \\
\text { the minimum } \\
\text { age of marriage } \\
\text { for girls? }\end{array}$ & $\begin{array}{c}\text { Under what } \\
\text { circumstances } \\
\text { can 15-year- } \\
\text { old girls be } \\
\text { married? }\end{array}$ \\
\hline Albania & 18 years old & 18 years old & $\begin{array}{c}\text { No difference } \\
\text { in minimum } \\
\text { age }\end{array}$ & $\begin{array}{c}\text { No minimum } \\
\text { age of marriage }\end{array}$ & $\begin{array}{c}\text { Only permitted } \\
\text { with court } \\
\text { approval and/or } \\
\text { pregnancy }\end{array}$ \\
\hline Bosnia and & 18 years old & 18 years old & $\begin{array}{c}\text { No difference } \\
\text { in minimum } \\
\text { Herzegovina }\end{array}$ & 16 years old & $\begin{array}{c}\text { Marriage } \\
\text { legally } \\
\text { prohibited }\end{array}$ \\
\hline Bulgaria & 18 years old & 18 years old & $\begin{array}{c}\text { No difference } \\
\text { in minimum } \\
\text { age }\end{array}$ & 16 years old & $\begin{array}{c}\text { Marriage } \\
\text { legally } \\
\text { prohibited }\end{array}$ \\
\hline
\end{tabular}




\begin{tabular}{|c|c|c|c|c|c|}
\hline Croatia & 18 years old & 18 years old & $\begin{array}{c}\text { No difference } \\
\text { in minimum } \\
\text { age }\end{array}$ & 16 years old & $\begin{array}{l}\text { Marriage } \\
\text { legally } \\
\text { prohibited }\end{array}$ \\
\hline Cyprus & 18 years old & 16 years old & $\begin{array}{c}\text { No difference } \\
\text { in minimum } \\
\text { age }\end{array}$ & 16 years old & $\begin{array}{l}\text { Marriage } \\
\text { legally } \\
\text { prohibited }\end{array}$ \\
\hline Macedonia & 18 years old & 18 years old & $\begin{array}{c}\text { No difference } \\
\text { in minimum } \\
\text { age }\end{array}$ & 16 years old & $\begin{array}{c}\text { Marriage } \\
\text { legally } \\
\text { prohibited }\end{array}$ \\
\hline Montenegro & 18 years old & 18 years old & $\begin{array}{c}\text { No difference } \\
\text { in minimum } \\
\text { age }\end{array}$ & 16 years old & $\begin{array}{c}\text { Marriage } \\
\text { legally } \\
\text { prohibited }\end{array}$ \\
\hline Serbia & 18 years old & 18 years old & $\begin{array}{c}\text { No difference } \\
\text { in minimum } \\
\text { age }\end{array}$ & 16 years old & $\begin{array}{l}\text { Marriage } \\
\text { legally } \\
\text { prohibited }\end{array}$ \\
\hline Slovakia & 18 years old & 18 years old & $\begin{array}{c}\text { No difference } \\
\text { in minimum } \\
\text { age }\end{array}$ & 16 years old & $\begin{array}{c}\text { Marriage } \\
\text { legally } \\
\text { prohibited }\end{array}$ \\
\hline Slovenia & 18 years old & 18 years old & $\begin{array}{c}\text { No difference } \\
\text { in minimum } \\
\text { age }\end{array}$ & $\begin{array}{l}\text { No minimum } \\
\text { age of marriage }\end{array}$ & $\begin{array}{l}\text { Only permitted } \\
\text { with court } \\
\text { approval and/or } \\
\text { pregnancy }\end{array}$ \\
\hline TURKEY & $\begin{array}{l}18 \text { years } \\
\text { old }\end{array}$ & 17 years old & $\begin{array}{c}\text { No difference } \\
\text { in minimum } \\
\text { age }\end{array}$ & 16 years old & $\begin{array}{c}\text { Marriage } \\
\text { legally } \\
\text { prohibited }\end{array}$ \\
\hline
\end{tabular}

Source: 2018 World Policy Analysis Center (34)

Compared Turkey with the Middle East Countries, the minimum age of marriage differs as per the county. In Yemen and Saudi Arabia, there is no minimum age of marriage, whereas in Lebanon it is 9. Besides Egypt, Israel and Turkey, under some circumstances 15-year-old girls can get married. The following table points out comparison between Turkey and Middle East Countries on the basic legal situations on child marriage. (34) (Table 5)

Table 5: Comparison Between Turkey and Middle East

\begin{tabular}{|c|c|c|c|c|c|}
\hline Country & $\begin{array}{c}\text { What is the } \\
\text { minimum } \\
\text { age of } \\
\text { marriage } \\
\text { for girls? }\end{array}$ & $\begin{array}{c}\text { What is the } \\
\text { minimum age } \\
\text { of marriage } \\
\text { for girls with } \\
\text { parental } \\
\text { consent? }\end{array}$ & $\begin{array}{c}\text { Is there a } \\
\text { gender } \\
\text { disparity in } \\
\text { the minimum } \\
\text { legal age of } \\
\text { marriage? }\end{array}$ & $\begin{array}{c}\text { When all } \\
\text { exceptions are } \\
\text { taken into } \\
\text { account, what is } \\
\text { the minimum } \\
\text { age of marriage } \\
\text { for girls? }\end{array}$ & $\begin{array}{c}\text { Under what } \\
\text { circumstances } \\
\text { can 15-year- } \\
\text { old girls be } \\
\text { married? }\end{array}$ \\
\hline Bahrain & 16 years old & 16 years old & $\begin{array}{c}\text { Girls can be } \\
\text { married } 2 \\
\text { years younger } \\
\text { than boys }\end{array}$ & $\begin{array}{c}\text { No minimum age } \\
\text { of marriage }\end{array}$ & $\begin{array}{c}\text { Data is not } \\
\text { available }\end{array}$ \\
\hline
\end{tabular}


DOI: 10.5281/zenodo.2667712

\begin{tabular}{|c|c|c|c|c|c|}
\hline Egypt & 18 years old & 18 years old & $\begin{array}{c}\text { No difference } \\
\text { in minimum } \\
\text { age }\end{array}$ & 18 years old & $\begin{array}{l}\text { Marriage } \\
\text { legally } \\
\text { prohibited }\end{array}$ \\
\hline Iran & 13 years old & 13 years old & $\begin{array}{l}\text { Girls can be } \\
\text { married } 2 \\
\text { years younger } \\
\text { than boys }\end{array}$ & $\begin{array}{l}\text { No minimum age } \\
\text { of marriage }\end{array}$ & No restrictions \\
\hline Iraq & 18 years old & 18 years old & $\begin{array}{c}\text { No difference } \\
\text { in minimum } \\
\text { age }\end{array}$ & 15 years old & $\begin{array}{l}\text { Only permitted } \\
\text { with court } \\
\text { approval and/or } \\
\text { pregnancy }\end{array}$ \\
\hline Israel & 17 years old & 17 years old & $\begin{array}{c}\text { No difference } \\
\text { in minimum } \\
\text { age }\end{array}$ & 16 years old & $\begin{array}{l}\text { Marriage } \\
\text { legally } \\
\text { prohibited } \\
\end{array}$ \\
\hline Jordan & 18 years old & 18 years old & $\begin{array}{c}\text { No difference } \\
\text { in minimum } \\
\text { age }\end{array}$ & 15 years old & $\begin{array}{l}\text { Only permitted } \\
\text { with court } \\
\text { approval and/or } \\
\text { pregnancy }\end{array}$ \\
\hline Kuwait & 15 years old & 15 years old & \begin{tabular}{|} 
Girls can be \\
married 2 \\
years younger \\
than boys
\end{tabular} & 15 years old & No restrictions \\
\hline Lebanon & 9 years old & 9 years old & \begin{tabular}{|c} 
Girls can be \\
married 4 \\
years younger \\
than boys \\
\end{tabular} & 9 years old & No restrictions \\
\hline Oman & 18 years old & 18 years old & $\begin{array}{l}\text { No difference } \\
\text { in minimum } \\
\text { age }\end{array}$ & $\begin{array}{l}\text { No minimum age } \\
\text { of marriage }\end{array}$ & $\begin{array}{l}\text { Only permitted } \\
\text { with court } \\
\text { approval and/or } \\
\text { pregnancy }\end{array}$ \\
\hline Qatar & 16 years old & 16 years old & \begin{tabular}{|c} 
Girls can be \\
married 2 \\
years younger \\
than boys \\
\end{tabular} & $\begin{array}{c}\text { No minimum age } \\
\text { of marriage }\end{array}$ & $\begin{array}{l}\text { Only permitted } \\
\text { with court } \\
\text { approval and/or } \\
\text { pregnancy }\end{array}$ \\
\hline $\begin{array}{l}\text { Saudi } \\
\text { Arabia }\end{array}$ & $\begin{array}{l}\text { No } \\
\text { minimum } \\
\text { age of } \\
\text { marriage }\end{array}$ & $\begin{array}{c}\text { No minimum } \\
\text { age of } \\
\text { marriage }\end{array}$ & $\begin{array}{l}\text { No minimum } \\
\text { age for girls } \\
\text { and boys }\end{array}$ & $\begin{array}{l}\text { No minimum age } \\
\text { of marriage }\end{array}$ & No restrictions \\
\hline Syria & 17 years old & 17 years old & $\begin{array}{c}\text { Girls can be } \\
\text { married } 1 \text { year } \\
\text { younger than } \\
\text { boys }\end{array}$ & $\begin{array}{l}\text { Data is not } \\
\text { available }\end{array}$ & $\begin{array}{l}\text { Data is not } \\
\text { available }\end{array}$ \\
\hline
\end{tabular}


DOI: 10.5281/zenodo.2667712

\begin{tabular}{|c|c|c|c|c|c|} 
TURKEY & $\mathbf{1 8}$ years old & $\mathbf{1 7}$ years old & $\begin{array}{c}\text { No difference } \\
\text { in minimum } \\
\text { age }\end{array}$ & 16 years old & $\begin{array}{c}\text { Marriage } \\
\text { legally } \\
\text { prohibited }\end{array}$ \\
\hline $\begin{array}{c}\text { United } \\
\text { Arab } \\
\text { Emirates }\end{array}$ & 18 years old & 18 years old & $\begin{array}{c}\text { No difference } \\
\text { in minimum } \\
\text { age }\end{array}$ & Puberty & $\begin{array}{c}\text { Only permitted } \\
\text { with court } \\
\text { approval and/or } \\
\text { pregnancy }\end{array}$ \\
\hline Yemen & $\begin{array}{c}\text { No } \\
\text { minimum } \\
\text { age of } \\
\text { marriage }\end{array}$ & $\begin{array}{c}\text { No minimum } \\
\text { age of } \\
\text { marriage }\end{array}$ & $\begin{array}{c}\text { No minimum } \\
\text { age for girls } \\
\text { and boys }\end{array}$ & $\begin{array}{c}\text { No minimum age } \\
\text { of marriage }\end{array}$ & No restrictions \\
\hline
\end{tabular}

Source: 2018 World Policy Analysis Center (34)

\section{Conclusion}

Child marriage is defined as a marriage before the age of 18. In many countries, a significant number of girls still marry before the age of 18 . The country governments and international communities are increasingly aware of the negative impacts of child marriages, but the actions to end the practice is still limited.

Ending child marriage is a part of the Sustainable Development Goals. Yet investments to end the practice remain limited across the globe and more could be done. (35)

Child marriage threatens particularly girls' lives and health, and it limits their future prospects. Girls pushed into child marriages often become pregnant while still adolescents, increasing the risk of complications in pregnancy and childbirth. These complications are the leading cause of death among older adolescent girls (36). In addition, early marriages have an impact on psychological and physical development of the children and these children are extremely vulnerable to domestic violence, abuse and abandonment. Large age gap between a child and her spouse makes her more vulnerable to physical, sexual or psychological abuse.

Early marriages are not considered as a "problem" by the majority of the society where as it is a phenomenon that has been existing for long years in our country. It is observed that one of the most important sources of legitimacy of marriage is public accord and these marriages are realized mostly in the framework of this accord. Patriarchal and traditional social structure have unfortunately normalized and legitimized early marriages.

Early marriages constitute a problem that prevent the exercise of human rights, undermines the status of women and deprive child from their main rights including especially the education. These marriages are a field that must be struggled with in Turkey targeting social gender equality.

It is necessary to hold meetings to create and develop awareness for implementation of Turkish Civil Code numbered 4721, Turkish Penal Code numbered 5237 and Law on Protection of Minors numbered 5395. It will be therefore possible to ensure that children, families and people understand what kind of problems and penal responsibilities that early marriage of children constitutes and that individuals orienting children to early marriage come to know that they are 
responsible as "instigator". And this will constitute an important step in elimination of child marriages.

In order to tackle child marriage more specifically, the current situation may need to be mapped in different regions and cities of Turkey. It may also be necessary to raise awareness on the effects of child marriages on children. There is also a need for debate on mufti law to prevention of child marriage.

It is also a significant point to set 18 as the minimum age of marriage without any exceptions and harmonise all illegal systems (civil law, criminal law, family law, customary law etc.) to this standard.

\section{References}

[1] https://data.unicef.org/topic/child-protection/child-marriage/ (Last accessed on 22.08.2018)

[2] https://www.girlsnotbrides.org/why-does-it-happen/ (Last accessed on 23.07.2018

[3] Jensten R, Thornton R. "Early Female Marriage in Developing World" Gender and Development 11, No. 2 (2003): 9-19.

[4] Jain S, Kurz K. "New Insights on Preventing Child Marriage: A Global analysis of Factors and Program" (report prepared by the International Center for reseach on the Women for the United States Agency for International Development, April 2007.

[5] UNICEF, Early Marriage: A Harmful Traditional Practice (New York: Unicef 2005)

[6] Ertem M, Saka G, Ceylan A, Değer A. "The Factors Associated with Adolescent Marriages and Outcomes of Adolescent Pregnacies in Mardin Turkey" Journal of Comperative Family Studies 39, No.2 (2008).

[7] Marthur S, Greene M, Malhotra A, "Too youmg to Wed: The Lives, Rights, and Healthy of young Married Girls",Washington D.C: International Center of Research on Women, 2003.

[8] Annan KA. "We the Children" (New york: UNICEF, 2001)

[9] Turkish Official Gazette, dated 08.12.2001 and numbered 24607.

[10] Committee on Equality of Opportunity for Women and Men of Turkish Parliamentary Report on Evaluation of Early Marriages, 2010. https://www.tbmm.gov.tr/komisyon/kefe/docs/komisyon_rapor.pdf (Last accessed on 22.08.2018)

[11] KADEM. Workshop Report on Fight against Early Marriages and Forced Marriages in Turkey, 2014 http://kadem.org.tr/erken-yasta-ve-zorla-evliliklere-karsi-mucadele-calistay-raporu/ (Last accessed on 22.08.2018).

[12] Ertürk Y. (Representative of METU). Committee on Equality of Opportunity for Women and Men of Turkish Parliamentary Minutes of the Sub-Commission Meeting dated 5/6/2009.

[13] Doğan S. (Representative of NGO named Uçan Süpürge). Committee on Equality of Opportunity for Women and Men of Turkish Parliamentary. Minutes of the Sub-Commission Meeting dated $8 / 6 / 2009$.

[14] Balaman AR. "Marriage Kinship Types" Ankara, (2002). Publications of Ministry of Culture of Turkish Republic: 44-45,

[15] Yasa İ. "Taygeldi Family", Ankara University Faculty of Political Science Journal, Ankara, (1962), Volume: 17, Issue: 2.

[16] Poyraz Tacoğlu T. "The Reasons for Traditional Marriages in Turkey and the Effects of Custom on Marriages". METU Institute of Social Sciences Journal of Social Sciences Research. ISSN: 1309-9302. Volume: 2 Issue: December 4, 2011: 114-143.

[17] Sezen L. "Marriage Types in Turkey", Ataturk University Turkish Intermediate Research Institute Journal, Issue: 27, Prof. Dr. Sinasi Tekin Special Issue, 2005: 185-195. 
[18] UNICEF, State of the World's Children, 2017.

[19] TURKSTAT. "Marriage and Divorce Statistics, 2017”, No: 27593, 02 March 2018.

[20] TURKSTAT. "Statistics on Children, 2017”, No: 27596, 18 April 2018

[21] Ministry of Family and Social Policies, 2010, 2011, 2012, 2013, 2014, 2015. https://odatv.com/tuyler-urperten-rakam--1904161200.html (Last accessed on 22.08.2018).

[22] Statistics of Ministry of Justice, 2017. http://www.adlisicil.adalet.gov.tr/istatistik_2017/ istatistik2017.pdf (Last accessed on 22.08.2018).

[23] Report of Committee on Human Rights of Turkish Parliamentary, 2010. http://www.radikal.com.tr/turkiye/siirtte-biri-10-yasinda-76-cocuk-anne-oldu-995523/ (Last accessed on 22.08.2018).

[24] B.Mensch. "The Transition to Marriage" in C.B. Lloyd ed., Growing Up Global: The Changing Transitions to Adulthood in Developing Countries, Committee on Population, Board on Children, Youthh, and Families, Division ov Behavioral and Social Sciences and Education, National Research Counsil, and Institute of Medicine (Washinigton D.C.: National Academies Press, 2005) 416-505.

[25] UNICEF. Press Release, New York, 6 March 2018. https://www.unicef.org/eca/press-releases/25million-child-marriages-prevented (Last accessed on 22.08.2018).

[26] UNICEF, Progress for Every Child in the SDG Era, March 2018.

[27] WHO, Press Release, New York, 7 March 2013. http://www.who.int/mediacentre/news/releases/2013/child_marriage_20130307/en/ (Last accessed on 22.08.2018).

[28] UNICEF Database. https://data.unicef.org/wp-content/uploads/2015/12/Child-marriage-database_Mar-2018.xlsx (Last accessed on 22.08.2018)

[29] Preamble of Turkish Civil Code, Main Commission Report No. 723. https://www.tbmm.gov.tr/sirasayi/donem21/yil01/ss723m.htm (Last accessed on 22.08.2018).

[30] http://www.mevzuat.gov.tr/MevzuatMetin/1.5.5237.doc (Last accessed on 22.08.2018).

[31] Court Decision of the Supreme Court of Appeal 5th Criminal Offic, dated 01/05/2007 and numbered 2007/3649 E - 2007/3120 K.

[32] Decree of the Constitutional Court, dated 27/5/2015 and numbered 2014/36 E. - 2015/51 K.

[33] World Policy Analysis Centre, Changing Children's Chances: New Findings on Child Policy Worldwide, 2013.

https://www.worldpolicycenter.org/sites/default/files/Childrens\%20Chances\%20Report\%20\%20English.pdf (Last accessed on 22.08.2018).

[34] World Policy Analysis Centre, Child Marriage Database. https://www.worldpolicycenter. org/datatables/policy/what-is-the-minimum-age-of-marriage-for-girls (Last accessed on 23.07.2018).

[35] World Bank, Economic Impacts of Child Marriage: Global Synthesis Report, June 2017. http://documents.worldbank.org/curated/en/530891498511398503/pdf/116829-WP-P151842PUBLIC-EICM-Global-Conference-Edition-June-27.pdf.

[36] https://www.unfpa.org/child-marriage (Last accessed on 22.08.2018).

\footnotetext{
*Corresponding author.

E-mail address: ouzpol@yahoo.com/z_reva@yahoo.com
} 